\title{
OFFICER-DIRECTOR RELIANCE ON CORPORATION COUNSEL'S ADVICE: A "GOOD FAITH" DEFENSE IN CONFLICT OF INTEREST CASES*
}

Transactions between corporations and officers or directors with conflicting interests ${ }^{1}$ have long been rigorously supervised by the courts. ${ }^{2}$ In actions brought on behalf of the corporation against officers or directors for waste or negligence, plaintiff must overcome judicial reluctance to interfere with management's business judgment. ${ }^{3}$ But once plaintiff has shown a possible conflict

${ }^{*}$ Spirt v. Bechtel, 232 F.2d 241 (2d Cir. 1956).

1. A conflict of interest may exist between directors and officers and their corporations in three common factual situations: when the directors contract with the corporation for salary or incentive compensation, Wight v. Heublein, 238 Fed. 321, 324 (4th Cir. 1916); Rosenthal v. Burry Biscuit Corp., 30 Del. Ch. 299, 304, 60 A.2d 106, 109 (Ch. 1948); when the director has an interest in another corporation which is dealing with his corporation, Globe Woolen Co. v. Utica Gas \& Elec. Co., 224 N.Y. 483, 121 N.E. 378 (1918) (interlocking directorate); Everett v. Phillips, 288 N.Y. 227, 237, 43 N.E.2d 18, 22 (1942) (same; but corporation charter contained provision, authorized by statute in many states, permitting transactions between interlocked corporations); when the director personally takes advantage of a business opportunity which the corporation might have exploited, Guth v. Loft, 23 Del. Ch. 255, 270-73, 5 A.2d 503, 510-11 (Sup. Ct. 1939); Greene v. Allen, 114 A.2d 916 (Del. Ch. 1955), rev'd sub nom. Johnston v. Greene, 121 A.2d 919 (Del. Sup. Ct. 1956). Courts and commentators frequently distinguish between breaches of a director's duty arising from his dealing with the corporation on his own behalf and those arising from transactions between management and third parties. The latter type of breach is classified as the usurpation of a "corporate opportunity." See 3 Fletcher, Cyclopedia of Corporations $\$ 8 \$ 4$ (perm. ed. rev. 1947) (hereinafter cited as FletCher).

2. Directors and officers are usually considered fiduciaries. 3 FLETCHER $\S 838 ; 3$ Bogert, Trusts and Trustees $\$ 543$ (1935) (hereinafter cited as BogerT) ; Uniform Fipuciaries ACr $\$ 1$. Courts of equity accordingly undertake to insure that officers and directors subordinate their personal interests to those of the corporation. Since a conflict of interest may often involve an injury to the interests of the corporation, the courts frequently apply very strict standards in these cases. Stevens, Private Corporattons $\S 148$ (2d ed. 1949) (hereinafter cited as STEvens). For discussion of the remedies available to the corporation see 4 PoMeroy, EQUity JURISPRUdence $\$ 1075$ (5th ed. 1941) (hereinafter cited as POMERoy); note 29 infra.

3. Predicated on criticism of the managerial policies of the board of directors, actions for waste and negligence are disfavored. Courts usually apply the "business judgment rule" and refuse to appraise acts of the board of directors unless plaintiff proves fraud, illegality or acts done ultra vires. The complainant also has the burden of proving causation and all the other elements of his case. Otis v. Pennsylvania R.R., 61 F. Supp. 905, 911 (E.D. Pa. 1945); Ellerman v. Chicago Junction Ry., 49 N.J. Eq. 217, 23 Atl. 287 (Ch. 1891) ; Casey v. Woodruff, 49 N.Y.S.2d 625, 642 (Sup. Ct. 1944). See Carson, Current Phases of Derivative Actions Against Directors, 40 Mrcr. L. Rev. 1125 (1942), Further Phases of Derivative Actions Against Directors, 29 CoRnetc L.Q. 431, 443 (1944); 13 FLETCEER $\$ \S 582 \$, 5867$ (perm. ed. rev. 1943). When plaintiff succeeds in proving fraud or negligence the corporation may recover an amount equal to its loss. Washington \& Rothschild, Compensating the Corporate Exrcutive 376 (rev. ed. 1951) (hereinafter cited as Washington \& RothisCHILD); 3 F FetCHeR $\S 1029$. 
of interest, courts frequently presume that any resulting transaction was in breach of duty. ${ }^{4}$ Intended largely to prevent breaches of fiduciary duty by deterring corporate officials from creating situations in which defections often occur, this rule is frequently unrealistic. ${ }^{5}$ In many situations which present possible conflicts of interests, the corporation's rights are circumscribed by $\operatorname{tax}^{6}$ or regulatory laws. ${ }^{7}$ Corporate officers and directors consequently must often rely on the advice of attorneys or other persons with expert knowledge to determine whether the corporation has an interest adverse to that of its officials. In these cases, a blanket presumption, denying reliance on expert advice would not only be unrealistic, ${ }^{8}$ but would often deprive directors or officers of reasonable profits honestly earned.9 Yet to excuse management

4. Once plaintiff has established facts which show a conflict of interest situation and a profit made by the director, the burden of proving absence of a breach of duty is placed on those seeking to uphold the transaction. Pepper v. Litton, 30S U.S. 295, 306 (1939) (dominant shareholder fixed his own salary); Gottlieb v. Heyden Chemical Corp., 33 Del. Ch. 82, 87-88, 90 A.2d 660, 663, limited rehearing, 91 A.2d 57 (Sup. Ct. 1952) (stock options issued to six out of nine directors) ; Solomine v. Hollander, 12S N.J. Eq. 228, 275-76, 16 A.2d 203, 228 (Ch. 1940) (directors allegedly bought for themselves business necessary to the corporation) ; cf. Perlman v. Feldmann, 219 F.2d 173 (2d Cir. 1955) (controlling shareholder usurped "tunmatured" corporate opportunity by selling control of corporation to a customer at a time when corporation might otherwise have $\mathrm{cx}$ ploited abnormal demand for its product). See Note, $68 \mathrm{HARV}$. L. REv. 1274 (1955); Rosenthal v. Burry Biscuit Co., 30 Del. Ch. 299, 306-07, 60 A.2d 106, 110 (Ch. 1948) (president dominated board and profited from stock option authorized by board).

In a minority of jurisdictions there is a conclusive presumption that a conflict of interest has resulted in a breach of duty to the corporation. See notes 26-27 infra.

5. Deterring future breaches is one of the primary purposes of the presumption. See cases cited note 28 infra and accompanying text. The presumption is also thought to facilitate compensation of the corporation when it suffers a loss. But see notes 29-31 infra and accompanying text. For indications that the rule is unrealistic, see STEvens $\$ \$ 14 \$, 149$ 147.

6. Truncale v. Universal Pictures, Inc., 76 F. Supp. 465 (S.D.N.Y. 1948) (corporation had possible tax deduction for the cost of its employee stock option plan which directors waived for their own personal gain); Bookman v. R. J. Reynolds Tobacco Co., 138 N.J. Eq. 312, 48 A.2d 646 (Ch. 1946) (same); Washington \& Rothschild 411-12. Cf. Johnston v. Greene, 121 A.2d 919, 926 (Del. Sup. Ct. 1956), reversing Greene v. Allen, 114 A.2d 916 (Del. Ch. 1955) (holding that tax considerations eliminated the possibility of the corporation obtaining patent rights; therefore there had been no usurpation of a corporate opportunity).

7. State, as well as federal, antitrust laws may prohibit the corporation from acquiring new business or properties. See, e.g., Blaustein v. Pan American Petroleum \& Transp. Co., 174 Misc. 601, 21 N.Y.S.2d 651 (Sup. Ct. 1940), modificd, 263 App. Div. 97, 31 N.Y.S.2d 934 (1st Dep't 1941), aff'd, 293 N.Y. 281, 56 N.E.2d 705 (1944) (Texas antitrust law construed by director of parent and subsidiary as permitting parent, but not subsidiary, to seize opportunity for expanding business).

8. Preston, Advice of Connsel as a Defense, 28 VA. L. Rev. 26, 43 (1941); Stevens $\S \S 148,149$.

9. The courts have recognized that corporate directors should, in certain situations, seek and follow the advice of counsel. See, e.g., Bates Street Shirt Co. v. Waite, 130 Me. 352, 369-70, 156 Atl. 293, 302-03 (1931) (advice of counsel who was an interested director, and of independent attorney, held to show directors' good faith although they 
whenever advice is obtained could well destroy the standards which courts have developed to bring fraudulent and unscrupulous officials to account. ${ }^{10}$

The Second Circuit, presented with this dilemma in Spirt v. Bechtel, ${ }^{11}$ held that officer-directors who had acted with due care and good faith in relying on the advice of counsel were not liable to the corporation. Two of the defendants had authorized an agreement between the Treasury Department and the corporation waiving the latter's claim to a tax deduction for expense incurred under its employee stock option plan. ${ }^{12}$ The other defendants had acquiesced in the waiver. As a result of the corporation's entering the agreement, the optionees under the plan, including the two authorizing officer-directors and several of the acquiescing defendant directors, were then entitled to treat their options as proprietary, rather than compensatory; their profits were consequently taxable at capital gains rates rather than at the higher rates applicable to ordinary income. ${ }^{13}$ The plaintiff, a shareholder

derived personal advantages); Litwin v. Allen, 25 N.Y.S.2d 667, 699 (Sup. Ct. 1940) (directors were negligent in not seeking advice of counsel before approving a plan held to be ultra vires); Orient Inv. \& Finance Co. v. Commissioner, 166 F.2d 601 (D.C. Cir. 1948), reversing 6 CCH Tax Ct. Mem. I 15546 (M) (1947) ("It was only natural justice" to free officers of the corporation from liability when they relied on a competent accountant's advice in a tax matter); cf. In re Kohler's Estate, $348 \mathrm{~Pa} .55,33$ A.2d 920 (1943) ; In re Wanamaker's Trust, $340 \mathrm{~Pa} .419,17$ A.2d 380 (1941) (advice of counsel as protection for the express trustee). But see Greene v. Allen, 114 A.2d 916, 918 (Del. Ch. 1955), rcv'd sub nom. Johnston v. Greene, 121 A.2d 919, 925 (Del. Sup. Ct. 1956) (reliance on expert advice, admittedly necessary, was ineffectual to protect defendants who had allegedly usurped a corporate opportunity). See, e.g., Simon, The Attorney-Client Privilege As Applied to Corporations, 65 YAle L.J. 953 (1956).

10. The business judgment rule, applied when no conflict of interest exists, seldom leads to liability on the part of directors. See note 3 supra; cf. Heller v. Boylan, 29 N.Y.S.2d 667, 680 (Sup. Ct. 1941).

11. 232 F.2d 241 (2d Cir. 1956), affirming in part 129 F. Supp. 872 (S.D.N.Y. 1955).

12. The stock option plan had been approved by the shareholders in May, 1943. 232 F.2d at 243. Under its provisions eight officers, seven of whom were directors constituting a majority of the board, were granted options. Brief for Appellants, pp. 7-10. Commissioner v. Smith, 324 U.S. 177 (1945), was decided prior to the exercise of the options. Immediately after this decision was announced, it was interpreted as giving the Commissioner the right to denominate all employee stock option plans as compensatory. T.D. 5507, 1946-1 Cum. Bull. 18; Washington \& Rothschind 131-32. In that event, upon exercise of the option the difference between the option price and the market price at the time the option was granted would be taxable as ordinary income to the optionee and deductible as salary expense by the corporation.

But in April 1946, I.T. 3795, 1946-1 CuM. BuLL. 15, was promulgated by the Commissioner, providing that, as to employee stock options granted before the Smith decision, rulings as to the consequences of exercising these options might be obtained. Pursuant to the advice of counsel, the president of the corporation (an optionee and director) requested a ruling. Brief for Appellees, p. 12. The ruling stated that the plan was not clearly compensatory. It further stated that it the corporation consented to waive its tax deduction and if all optionees also filed consents, the stock option plan would be treated as proprietary rather than compensatory.

13. If the stock options were proprietary in nature, the transaction would be taxable at the time the stock was sold, and then at capital gains rates. Malcolm S. Clark, P-H 
suing on behalf of the corporation, ${ }^{14}$ alleged that in authorizing or consenting to the corporation's waiver the defendant officers and directors had breached their duty of loyalty to the corporation. ${ }^{15}$ The defendants offered their reliance on the advice of the corporation's counsel as evidence that the transaction involved no conflict of interest and hence no question of loyalty, since, in counsel's opinion, the corporation was not entitled to take the tax deduction. ${ }^{10}$ The majority reasoned that the officer-directors were entitled to rely on this advice and further that, since the transaction involved no conflict of interest, the directors acted within the allowable limits of business discretion in electing to waive what seemed to them a doubtful claim. ${ }^{17}$

In permitting the directors to rely on the advice of counsel, the court followed a series of cases which have judged directors' conduct by objective standards when determining whether a conflict of interest existed between them and the corporation. Corporate opportunity cases, for example, have been decided on the basis of a factual question such as: the extent of the corporation's efforts to seek an opportunity like the one in question $;^{18}$ the

1950 T.C. Mem. Dec. If 50210; James M. Lamond, P-H 1946 T.C. Mem. Dec. đ 46023; Delbert B. Geeseman, 38 B.T.A. 258 (1938); Washington \& Rothschild 134.

14. Should directors refuse to bring suit, or should it appear plain that a request to them to do so would be fruitless, as when suit is based on the corporation's claim against a majority of the directors, a shareholder may bring a derivative action on behalf of the corporation. See, e.g., FED. R. CIV. P. 23(b) (regulating the right to bring derivative actions in the federal courts) ; Cohen v. Beneficial Industrial Loan Corp., 337 U.S. 541 (1949) ; Levitan v. Stout, 97 F. Supp. 105, 111-15 (W.D. Ky. 1951) ; 13 FLETCHER \& 5822; Comment, 45 YALE L.J. 649, 665-66 (1936).

15. 232 F.2d 241 at 245. See also Truncale v. Universal Pictures, Inc, 76 F. Supr. 465 (S.D.N.Y. 1948) (directors' waiver of corporation's claim to a tax deduction held sufficient to establish a claim for relief) ; Riddle v. Mary A. Riddle Co., 142 N.J. Eq. 147, 156, 59 A.2d 599, 604 (Ch. 1948) (directors have a duty to keep the corporation's liability under the Internal Revenue Laws as low as that law permits); WasHington \& RothsCHILD 133, 411.

16. 232 F.2d at 242 ; Brief for Appellees, p. 12.

17. $232 \mathrm{~F} .2 \mathrm{~d}$ at 247 . If no conflict of interest is involved the courts invoke the normal presumption used in cases of business judgment and will not interfere with the directors' discretion unless the results raise the inference that no judgment, in fact, was exercised. See note 3 supra. Absent proof of bad faith motivating their decision, directors breach no duty by refusing to litigage a corporate claim; they may be protected by their refusal to do so on the advice of counsel. Ballantine, Handbook of Corporations $\$ 147$ (1946) (hereinafter cited as Ballantine); 4 Cook, Corporations $\$ 750$ ( 8 th ed. 1923); Hornstein v. Paramount Pictures, Inc., 37 N.Y.S.2d 404, 418 (Sup. Ct.), aff'd, 266 App. Div. 659, 41 N.Y.S.2d 210 (1st Dep't), aff'd, 292 N.Y. 468, 55 N.E.2d 740 (1942) (disinterested directors' decision, based on the advice of the legal membur of the board, not to sue past and present directors, held sufficient defense against a charge of fraud) ; Findley v. Garrett, 109 Cal. App. 2d 166, 175-79, 240 P.2d 421, 427-31 (1952) (same) ; United Copper Co. v. Amalgamated Copper Co., 244 U.S. 261 (1917) (same).

18. Compare Guth v. Loft, 23 Del. Ch. 255, 5 A.2d 503 (Sup. Ct. 1939) (the corporation was seeking an opportunity like the one seized by the director, who used corporate facilities in exploiting the opportunity), with Lincoln Stores, Inc. v. Grant, 309 Mass. 417, 422, 34 N.E.2d 704, 707 (1941) (negotiations to acquire property for cor- 
corporation's financial ability to take advantage of the opportunity $;^{19}$ the director's purchase of an opportunity and subsequent resale to the corporation at a profit; $; 0$ or even whether the situation presented a special or unique opportunity necessary to the corporation's business or growth. ${ }^{21}$ Thus, although it is frequently said that the individual director's good faith is immaterial, ${ }^{22}$ these and other conflict of interest cases seem to use objective tests of good faith ; they suggest that a conflict of interest can exist only when a reasonably prudent director could not in good faith have acted as the individual defendant did. And when no conflict exists, they hold that the director had no absolute duty to refrain from realizing a personal profit. Spirt in effect continues the reasoning of these cases. ${ }^{23}$ It adds reliance on the advice of counsel to the list of

poration had been discontinued several years before the defendant acquired similar property for himself); Colorado \& Utah Coal Co. v. Harris, 97 Colo. 309,49 P.2d 429 (1935) (fact that company had once considered the purchase is not sufficient to constitute "sceking").

19. Hauben v. Morris, 255 App. Div. 35, 47, 5 N.Y.S.2d 721, 731 (1st Dep't 1938), $a f f^{\prime} d, 281$ N.Y. 652, 22 N.E.2d 482 (1939); Presidio Mining Co. v. Overton, 261 Fed. 933, 962-63, 965 (9th Cir. 1919) ; Hannerty v. Standard Theatre Co., 109 Mo. 297, 19 S.W. 82 (1892). But see Irving Trust Co. v. Deutsch, 73 F.2d 121, 124 (2d Cir. 1934), cert. denicd, 294 U.S. 708 (1935) (financial inability held to mean near insolvency, not merely apparent inability to secure further credit).

20. Intent to resell to the corporation implies knowledge that the corporation is in the market for the opportunity. New York Trust Co. v. American Realty Co., 244 N.Y. $209,219,155$ N.E. 102, 105 (1926) (when director buys land intending to resell to his corporation, he must account to it for the profits); Durfee v. Durfee \& Canning Co., 323 Mass. 187, 200, 80 N.E.2d 522, 529-30 (1948) (forming business with intent to resell its product to the corporation diverts its profits) ; Blaustein v. Pan American Petroleum \& Transp. Co., 174 Misc. 601, 21 N.Y.S.2d 651 (Sup. Ct. 1940), rev'd on other grosnds, 263 App. Div. 97, 115, 31 N.Y.S.2d 934, 953 (1st Dep't 1941), aff'd, 293 N.Y. 281, 56 N.E.2d 705 (1944) (parent company held liable for not obtaining oil properties for the subsidiary, and for reselling oil to the subsidiary at a profit); Lincoln Stores, Inc. v. Grant, 309 Mass. 417, 423, 34 N.E.2d 704, 707 (1941) (alternate holding; officers not liable for acquiring property without intent to resell to the corporation).

21. Guth v. Loft, 23 Del. Ch. 255, 274, 5 A.2d 503, 512 (Sup. Ct. 1939) (secret formula held to be essential to the corporation's business); Litwin v. Allen, 25 N.Y.S.2d 667,690 (Sup. Ct. 1940) (shares of stock which defendant directors bought held not to have been desirable or necessary to the corporation); Solomine v. Hollander, 128 N.J. Eq. $228,253,16$ A.2d 203, 218 (Ch. 1940) (alternate holding; alleged corporate opportunity held to be unnecessary and extraneous to the purposes of the corporation). See Irving Trust Co. v. Deutsch, 73 F.2d 121 (2d Cir. 1934), cert. denied, 294 U.S. 708 (1935); Note, 44 Y ILE L.J. 527 (1935).

22. See, e.g., Seagrave Corp. v. Mount, 212 F.2d 389, 397 (6th Cir. 1954); Heise v. Earnshaw Publications Inc., 130 F. Supp. 38, 40 (D. Mass. 1955) ; Levitan v. Stout, 97 F. Supp. 105, 117 (W.D. Ky. 1951) (dictum); Spirt v. Bechtel, 232 F.2d 241, 256 (2d Cir. 1956) (dissenting opinion, citing 3 Bogert $\$ 493$, at 161; Restatentent, Trusts $\$ 201$ (1935)). Contra, Solomine v. Hollander, supra note 21 , at 246,16 A.2d at 215 (stating that good faith is one of five facts which may negate the existence of a corporate opportunity); cf. Greene v. Allen, 114 A.2d 916, 920 (Del. Ch. 1955), rev'd sub nom. Johnston v. Greene, 121 A.2d 919 (Del. Sup. Ct. 1956) (assuming but declining to decide whether good faith would be a defense).

23. Authorities adopting objective tests of good faith disagree as to what the tests should be. E.g., compare Lagarde v. Anniston Lime \& Stone Co., 126 Ala. 496, 502, 28 
objective tests of good faith applicable whenever a question of the existence of a conflict of interest arises.

When reliance on advice of counsel is introduced to refute an allegation of conflict of interest, an objective test of good faith strikes a reasoned mean between two undesirable extremes. A subjective test of judging the individual director's good faith ${ }^{24}$ is unworkable. This approach too frequently requires the courts to evaluate the business judgment or ability of corporate officials, a duty which the courts are reluctant to assume because to do so would, they feel, unreasonably inhibit honest directors from exercising their discretion. The subjective test, consequently, may fail to safeguard the interests of the corporation. ${ }^{25}$

The other extreme, the strict rule of liability followed in a minority of jurisdictions, is unjustifiable. ${ }^{26}$ Some courts conclusively presume that whenever a director has realized a profit from a transaction in which he acted both for himself and for the corporation, he has breached his duty to the corporation. $^{27}$ Apart from the fact that in areas in which reliance on expert advice

So. 199, 201 (1900) (only test is whether there is an existing interest or expectancy on the part of the corporation in the property in question or whether officer's interference will balk the corporation in effecting the purpose of its creation), with Solomine v. Hollander, 128 N.J. Eq. 228, 247, 16 A.2d 203, 215 (Ch. 1940) (listing, in addition to the criteria of notes 19 and 20 supra and accompanying text, whether director competes directly with his corporation); Comment, 31 Calif. L. Rev. 188, 189 (1943).

24. Blaustein v. Pan American Petroleum \& Transp. Co., 174 Misc. 601, 687, 21 N.Y.S.2d 651, 731 (Sup. Ct. 1940), rev'd, 263 App. Div. 97, 115, 31 N.Y.S.2d 934, 953 (1st Dep't 1941), aff'd, 293 N.Y. 281, 56 N.E.2d 705 (1944) (all courts considered that defendant directors had acted in good faith as individuals; lower court still held them liable for usurping a corporate opportunity) ; Gottlieb v. Heyden Chemical Corp., 33 Del. Ch. 82, 87, 90 A.2d 660, 663 (Sup. Ct. 1952) (reversing lower court which had based its decision, in part, on directors' affirmation of their individual good faith).

25. The inability, whether real or self-imposed, of some courts to examine a decision from the point of view of business conditions existing at the time, and their consequent unwillingness to declare it unfair unless the results are grossly inequitable to the corporation, may leave unremedied results which are detrimental to the corporation and beneficial to the directors. Rogers v. Hill, 50 F.2d 109, 113 (2d Cir. 1932) rev'd, 289 U.S. 582, 591-92 (1933) ; Rogers v. Guaranty Trust Co., 60 F.2d 114, 119 (2d Cir. 1932), rev'd other grounds, 288 U.S. 123, 150 (1933) ; Blaustein v. Pan American Petroleum \& Transז'. Co., 263 App. Div. 97, 122, 31 N.Y.S.2d 934, 959 (1st Dep't 1941), aff'd, 293 N.Y. 281, 56 N.E.2d 705 (1944) ; Heller v. Boylan, 29 N.Y.S.2d 667, 680 (Sup. Ct. 1941). Judicial refusal to reappraise the business situation thus creates an almost irrebuttable presumption of good faith on the part of the directors. Even when the burden of persuasion on this issue falls upon the directors, the shareholder's attempts to refute evidence of good faith introduced by the directors have often been unsuccessful. Washington \& Rotrschin.n $375 \&$ nn.45, 46, 416. But see Greene v. Allen, 114 A.2d 916, 920 (Del. Ch. 1955), rev'd sub nom. Johnston v. Greene, 121 A.2d 919 (Del. Sup. Ct. 1956) (recognizing that to adopt subjective test of good faith would place difficult burden on shareholder, but holding that directors failed to show good faith).

26. For more detailed discussions of this rule, and indications of the jurisdictions where it is followed, see Notes, 39 CoLum. L. Rev. 219 (1939); 44 Y ALE L.J. 527 (1935): 51 Yale L.J. 1034, 1038 (1942); Ballantine $\$ \$ 67,72 ; 3$ Bogert $\$ \$ 543,493$.

27. Irving Trust Co. v. Deutsch, 73 F.2d 121 (2d Cir. 1934), cert. denicd, $29+$ U.S. 
is absolutely essential this presumption fails to serve its primary purpose of deterring breaches, ${ }^{28}$ it hinders full compensation for breaches when they actually do occur. For normally directors held liable under the constructive fraud rule are required to pay over to the corporation the profit they realized. ${ }^{29}$ The Spirt situation illustrates but one of numerous conflict of interest situations in which the directors' profit may be less than the corporation's loss. ${ }^{30}$ To hold the directors liable for the larger amount when they have relied on counsel would aggravate the harshness of the presumption. ${ }^{31}$ Moreover, whichever measure of damages may be applied, a conclusive presumption, while it seems designed jealously to protect corporations, may actually harm them by discouraging competent men from assuming responsibility as directors. The Spirt holding, however, has neither of these disadvantages. Rather it protects directors who have followed expert advice on appropriate occasions. And, since it establishes a more discerning standard of breach of duty, it allows the corporation to recover compensation for its loss when negligence or actual fraud are present.

$70 S$ (1935) ; Seagrave Corp. v. Mount, 212 F.2d 389 (6th Cir. 1954). See Stevers $\$ 148$, at 678-79; Notes, 53 Mrch. L. Rev. 472 (1955); 39 MrCH. L. Rev. 314 (1940).

28. Irving Trust Co. v. Deutsch, supra note 27 ; Rogers v. Guaranty Trust Co., 288 U.S. 123, 150 (1932) (dissenting opinion of Cardozo, J.); Barrantrne $\$$ 67; See Stevens at 678; see also notes 5-8 supra and accompanying text.

29. If the director's realization of a profit or benefit from his dealings with the corporation, or from dealings with others in which his fiduciary position is involved, is deemed per se a breach of duty, the director is ordinarily declared a constructive trustee of the property, profits or proceeds, and ordered to convey to the corporation. 4 PoMreroy $\$ \$ 1049,1050$, 1053, 10S9. Recovery thus is determined by benefit to the director rather than harm to the corporation. Fleischhacker v. Blum, 109 F.2d 543 (9th Cir.), cert. denied, 311 U.S. 665 (1940) (award to corporation of profits realized by an officer who used his position to derive a bonus from a third party); Gamlin v. Gamlin Chemical Corp., $79 \mathrm{~F}$. Supp. 622 (W.D. Pa. 1948) ; Production Mach. Co. v. Howe, 327 Mass. 372,99 N.E.2d 32 (1951).

When the director's liability is based on a finding of actual, rather than constructive, fraud, the corporation may obtain compensatory damages equal to its loss. See note 3 supra. It seems unlikely, however, that courts would award compensatory damages greater in amount than the gain realized by the directors unless they are found to have committed actual fraud. See notes 18-23 supra and accompanying text.

30. In Spirt it would be possible for the sum of the officer-directors' individual tax savings to be less, as well as more, than the amount of the corporation's loss from its failure to take a $\$ 1,200,000$ tax deduction, depending on the individual income tax rates of the officials in comparison to that of the corporation. See note 12 supra. Since the opportunity of which defendants availed themselves was not correlative with that which might otherwise have been open to the corporation, the traditional restitutionary remedy would not necessarily recompense the corporation for its loss. See Truncale v. Universal Pictures, Inc., 76 F. Supp. 465 (S.D.N.Y. 1948); note 6 supra.

31. If the defendants in Spirt had been held liable for the corporation's loss, the amount of liability would be commensurate neither with the advantages by which they had been enriched, nor with the existence of actual fault on their part, since no finding of bad faith had been made. See note 11 supra and accompanying text. See also Heller v. Boylan, 29 N.Y.S.2d 653, 667 (Sup. Ct. 1941) (court considered hardship to directors of requiring them to refund payments on which they had already paid income taxes). 
The Spirt court, however, seems to suggest that when the corporation's rights depend on questions of law reliance on any advice of any counsel would protect directors. ${ }^{32}$ Officials should be allowed to rely on a statement by the corporation's counsel that the corporation has no interest in the particular transaction, but the qualifications of counsel should be carefully scrutinized. When the transaction involves a specialized area of law, particularly tax or regulatory law, counsel should be experienced in that area. ${ }^{33}$ In addition, two factors may sometimes decrease the objectivity of counsel's advice. Frequently counsel participate in formulating a corporate plan or course of action, and in so doing they may base their decisions in part on nonlegal, business policy considerations. Judgments formed in this manner may unduly influence these participants if they are asked to give a legal opinion on the plan when it is completed. ${ }^{34}$ And counsel may in some cases be prejudiced by their economic interests; not only may they have a personal interest in the proposed transaction, ${ }^{35}$ but they may be heavily dependent financially on the particular corporation. In either case, counsel will have an incentive to give an opinion which would, at the same time, approve the plan and protect those who sponsor

32. See Spirt v. Bechtel, 232 F.2d 241, 256 (2d Cir. 1956) (dissenting opinion).

33. Aside from the usual requirements for the practice of a profession, academic training and admission by that profession to its membership, in the specialized regulatory fields further accreditation is required. Eleven administrative agencies have enrolled bars and formal requirements for admission to practice before them. Vom Baur, Representation Before Administrative Agencies, 30 N.Y.U.L. Rev. 1297, 1305 (1955). In addition, an amendment to the Canon of Ethics of the legal profession recognizes patent and admiralty law as specialities. Joiner, Specialization in the Laze? The Medical Profession Shows the Way, 39 A.B.A.J. 539 (1953). See Lewis, What is Competent Tax Adtice?, 28 Taxes 33 (1950) ; Hermax Co. v. Commissioner, 175 F.2d 776 (3d Cir. 1949), affirming 11 T.C. 442 (1948) (in pleading reliance on the advice of counsel to establish good faith in order to avoid tax penalties, the lay taxpayer must prove the competency of his tax counselor). These and similar standards of accreditation should be considered by the courts when deciding whether directors were justified in obtaining and following the advice they received. See, e.g., Preston, supra note 8 , at 26; cf. Note, 53 CoLuM. L. Rev. $374,378,385$ (1953) (stating standards for and advocating reliance on the interpretation of regulations by qualified government officials, as a protection from damages and penalties).

34. Preston, supra note 8 , at 48 . Thus, company or "house counsel," being involved in business policy formulation, may be so identified with a proposal as to make it dificult for them to objectively appraise its legal consêquences. This is but one factor to be considered in determining the justifiability of reliance on their advice. Tweed, The Changing Practice of Law, 11 RECORD of Ass'N of BAR of CrTY of N.Y. 13, $20-21$ (1956). But see Davis, House Counsel; The Lawyer With A Single Client, 41 A.B.A.J. 830 (1955); Berle, Changing Role of the Corporation And Its Connsel, 10 ReCORd of Ass'N of BAR of CITY of N.Y. 268, 278 (1955). Simon, supra note 9, at 957, 986-\$9 (suggesting that corporate counsel should not serve as director's or officer's personal counsel).

35. Blaustein v. Pan American Petroleum \& Transp. Co., 174 Misc. 601, 687, 21 N.Y.S.2d 651, 731 (Sup. Ct. 1940) (counsel, a director, was affiliated with the parent corporation whose interests were alleged to be adverse to those of the complaining subsidiary). Cf. United States v. United Shoe Mach. Corp. 89 F. Supp. 357, 360 (D. Mass. 1950) (house counsel differentiated from some outside firms only by organizational arrangement $r$ ). 
it. $^{30}$ And this may occasionally be true of outside counsel who are heavily dependent on the corporation, as well as house counsel. ${ }^{37}$

Similarly, a director's reliance on the advice of counsel may be based on a two-fold misunderstanding. The attorney's opinion can of course be of little value if based on a misapprehension of the facts $;^{38}$ and when the opinion is based on assumptions, it is of little value unless the assumptions are clearly stated. The advice, moreover, may be too complex to be fully comprehensible when stated orally. In addition, the facts given to the attorney and the resulting advice may be ambiguous. ${ }^{39}$

These sources of misunderstanding can be eliminated when the advice of counsel is embodied in an opinion letter. The letter should set forth the facts upon which the opinion is based and the name of the corporate official furnishing the information. The conclusions reached and the course of action advised should also be fully stated, and the letter should be dated and signed. Apart from the fact that these statements would simplify the problem of proving what was said by the corporation and by counsel, the formality of such an opinion letter would probably encourage both parties to insure that the relevant facts have been thoroughly and fairly stated. More important, a lawyer, or indeed any expert, knowing that his opinion not only will be relied upon, but also will be examined in court and possibly published in the court's opinion,

36. Cf. In re Bond \& Mortgage Guarantee Co., 303 N.Y. 423, 430-31, 103 N.E.2d 721, 725 (1952). But see Bates Street Shirt Co. v. Waite, 130 Me. 352, 369, 156 Atl. 293, 302 (1931) (directors protected in relying on "interested" counsel where independent advice was also obtained).

37. Cf. United States v. United Shoe Mach. Corp., 89 F. Supp. 357, 360 (D. Mass. 1950). Although counsel's economic independence may thus be in issue, counsel would not be required to make disclosures which would be useful to other attorneys or which would restrict counsel's freedom to set the fees charged their clients. See 8 Wramore, Evidence $\$ \$ 2196,2200$, at $117, \$ 2212$ (3d ed. 1940). Counsel who are independent could normally offer oral testimony of the percentage of their income derived from, or time devoted to, the defendant corporation and its directors. MCCoRMrck, Evidence $\$ 98$, at 198 (1954); 6 WIGMORE, op. cit. supra $\$ 1911$, at 606 . If plaintiff attempts to oppose or impeach this evidence by compelling counsel to produce their books, the cumulative evidence rule could be used by counsel to keep their books out of evidence. See 6 WIGMore, op. cit. supra $\$ \$ 1907$, $1908(3)$. When the books are necessary to resolve any uncertainty, they could be shown to the court alone. Cf. 8 id. $\$ 2212$.

38. See E. M. Green, 11 B.T.A. 278 (1928) ("It appears . . . that Green did not turn over to counsel complete information with respect to his income . . . which indicates to our mind that a part of the deficiences due ... was due to fraud.") ; Genesee Valley Gas Co., 11 T.C. 184 (1948) (failure affirmatively to question tax advisers as to alternatives was wilful neglect).

39. If the directors have not in fact followed the advice of counsel, but have misunderstood it and taken another course, they should not be protected by a presumption of good faith raised by their mistaken reliance. See notes 41-42 infra and accompanying text. Although normally directors are allowed to make such errors as a reasonably prudent director might make without incurring liability, in this situation deviation from the suggested course of conduct raises a question of the director's good faith in seeking and obtaining advice, and it destroys the corporation's safeguard of having the directors follow a course suggested in a reasonably competent legal opinion. 
can be expected to strive for objectivity. ${ }^{40}$ In fact, realizing that his objectivity or competence may be questioned, the advisor may also be expected to consider whether to disqualify himself.

When an opinion letter appears on its face to meet the requirements stated above, it should be sufficient to sustain the officials' burden of showing that they did not breach their duty to the corporation. ${ }^{41}$ Similarly, advice not formalized in an opinion letter should protect the directors if they can show that the advice was objectively given on the basis of adequate information, and that it was followed. In either event, however, this defense should be rebuttable. The plaintiff should be permitted to introduce evidence tending to show that the directors were not justified in relying on the advice because they knew or should have known it was, for example, prejudiced or carelessly given. This evidence should be weighed, along with the nature and seriousness of any error discovered in the opinion, in order to determine whether the directors acted in a reasonably prudent manner in seeking and accepting the advice. ${ }^{42}$ This procedure seems adequately designed to protect the interests of the corporation and, at the same time, permits honest directors confidently to rely on competent advice. And by presuming that a formal opinion letter is sufficient to justify action based upon it, the courts can encourage corporate officials to seek considered advice whenever expert knowledge is needed to determine whether a conflict of interest exists.

40. The corporate client should be permitted to introduce the opinion letter in evidence even though counsel whose advice is embodied in the letter attempts to assert the attorney-client privilege. The privilege is the client's and he may waive it. United States v. United Shoe Mach. Corp., 89 F. Supp. 357, 358 (D. Mass. 1950) ; 8 Wignore, Evidence $\S \S 2292$, 2321, 2327 (3d ed. 1940). See also, e.g., Matter of Robinson, 140 App. Div. 329, 336, 125 N.Y. Supp. 193, 199 (1st Dep't 1910) (an attorney, director of a corporation, could not claim attorney-client privilege for information obtained as a director). If the corporate client deliberately fails to follow the advice of counsel, after having secured an opinion letter, the interested directors or officers could not claim a privilege with regard to this communication on their part, unless they had clearly been consulting counsel alone, and, in a personal capacity. Simon, supra note 9, at 988 . And it might be a breach of ethics for corporate counsel to serve as director's or officer's personal counsel. Id. at 957 \& n.13.

41. See note 4 supra. If not rebutted, the opinion letter should thus be conclusive as to defendants' loyalty to the corporation, negating an allegation that because conflicting interests prejudiced their decision it was not reached in a manner consistent with the business judgment rule. See note 3 supra.

42. For example, plaintiff should be permitted to show that the facts given the advisor were not true and complete, that the advisor was not competent and objective, that the advice was not given on the day stated, or that the advice was not in fact relied upon when the directors decided to follow the course of action under attack. And he should, in addition, be permitted to show that the directors knew or ought to have known of any defect established. But see, e.g., RestateMrent, AgENCY \& 383(b) (1933).

When such defects are established, the court should also consider: the excusability of any error discovered in the advisor's opinion; and the money and time saved by the choice of this advisor rather than one who met the test of independence. 